\title{
Contamination and Supply Chain Issues in Food Safety
}

\author{
Mohd Hafiz Bin Mohamad Zahari ${ }^{1}$, Elias Kamaruzzaman², Samsudin Wahab ${ }^{3}$, Adi Izhar \\ Che Ani ${ }^{4}$, Mohd Rozaiman Aziz ${ }^{5}$ \\ \{hafizmz@yahoo.com ${ }^{1}$, eliask@gmail.com², samsudinw@uitm.edu.my ${ }^{3}$, adiizhar@uitm.edu.my ${ }^{4}$, \\ man@uitm.edu, $\mathrm{my}^{5}$ \} \\ Universiti Teknologi MARA, Cawangan Pulau Pinang, Malaysia ${ }^{1}$, Universiti Teknologi MARA, \\ Cawangan Pulau Pinang, Malaysia ${ }^{2}$, Universiti Teknologi MARA, Cawangan Pulau Pinang, Malaysia ${ }^{3}$, \\ Universiti Teknologi MARA, Cawangan Pulau Pinang, Malaysia ${ }^{4}$, Universiti Teknologi MARA, \\ Cawangan Pulau Pinang, Malaysia ${ }^{5}$
}

\begin{abstract}
The method of food processing offers many possibilities for contamination at different levels. The consequence of inappropriate use of agrochemicals, fertilizers, and pesticides in the field, and antibiotics and anti-parasitic agents in animal agriculture will lead to unsafe compounds in food products. Also, the bacteria and harmful microorganisms contaminate foods that can be spread through sub-optimal storage and transport processes. In food production, the use of unlawful additives will further contaminate food products. The difficulties and time-consuming to trace the origin of the commodity due to complicated long supply chain where involved the processes from raw materials to the final customer lead to great attention from academic researchers to study on the food and agricultural supply chain.
\end{abstract}

Keywords: Food contamination, Supply Chain, Food Safety.

\section{Introduction}

57 percent increased from 30 cases in 2015 to 45 cases in 2016 was reported from food poisoning [1]. The major contribution of the food poisoning is from schools and institutions which 47 out of 60 cases are reported under the Ministry of Education. The school canteens and kitchens affected most of the incidences. The infection on raw materials, crosscontamination during handling, and four hours early in cooking before serving time are the main factors of food poisoning as well as misuse of temperature during preparation, shipping, sales, and storage. Food poisoning incidences in Malaysia have risen dramatically from 2005 to 2013 and have also caused several cases of mortality [2].

\section{Literature Review}

\subsection{Food Contamination}

The food processing method presents many possibilities for contamination at different levels. The unsafe compounds in food products from the main production are caused by improper use of agrochemicals, fertilizers, and pesticides in the field, as well as antibiotics and anti-parasitic agents, use in animal agriculture. Besides, suboptimal storage and transportation will cause bacteria and harmful microorganisms to contaminate foods. Food products will become contaminated by using illegal food-processing chemicals [3]. 
Indeed, the issue of agricultural land and freshwater sources were caused by chemical contamination [4]. The growth in food safety issue was led by the field of pollution from industrial waste like heavy metals as the number of industrial facilities is increased in rural areas affecting the agricultural land. Heavy metal in contaminated soil and water, for example, will contribute to the toxicity exposure in agricultural products. This toxicity will lead to a variety of health risks when ingested and cause a higher risk of certain cancers by renal failure and then cause osteoporosis.

\subsection{Supply Chain Issues}

One of the important ways to ensure product safety is by monitoring product production and efficient logistics management in food and agricultural supply chains. It is becoming a higher concern to improve traceability in the supply chain when it is involved in food safety and contamination risks [5]. The trading of agricultural products across multiple countries requires accurate monitoring and compliance with country-specific regulations. Traceability of goods in the agricultural supply chain demands that sensitive information be gathered, shared, and handled by specifically identifying the origin, various exchanges of information within the supply chain. The difficulties in monitoring and tracking are caused by the complicated nature of information systems in the agricultural and food supply chain from multiple intermediaries in the production, processes, and transmission products [6].

In response to food safety issues, new policies, standards, and laws were developed for the food industry for food safety and control. Furthermore, the food industry has been introduced to integrated quality and food safety management systems for quality assurance as a pillar of food safety policy [5]. A tool to comply with the regulation and meet the requirement of food safety and food quality is the traceability system. This system will be an important safety and quality monitoring and tracking system to enhance food supply chain management and the trust of customers will be increased [7].

\section{Methods}

This paper represents the literatures on food contamination and supply chain issues in complying the SOP and standard for food safety practices among entrepreneurs. This basis article is on the earlier stage of proposal before conducting a real field research to prove the hypothesis. Therefore, this article is discussing the reviewed of available literature about contamination and supply chain variable as the determinants of food safely.

\section{Result and Discussion}

\subsection{Improving the quality and safety within food supply chain management}

A modern decentralized information system could become a revolutionary breakthrough that could include a knowledge network focused on openness, accountability, neutrality, reliability, and protection for all members of the supply chain (including government departments and third-party regulators).

Establishing a traceability system for the food supply chain for real-time food tracking, creating a safety control system for the food supply chain by integrating it with the general supply chain risk management methods, and significantly improving the efficiency of the food 
logistics sector [8]. It is possible to monitor, control, plan, and refine food supply chains remotely and in real-time from the Internet based on virtual objects rather than on-site inspection. To track the location of such items and trace their past, digital supply chains rely on food traceability systems.

To collect state information on items of interest over the life cycle, RFID and sensor technology are used. This could entail temperature control, microbiological awareness, and other food safety parameters [9].

\subsection{Enhance information security in the food supply chain}

It offers a permanent record for any business segment that has been sorted into separate blocks and can not be tampered with. It will replace the old paper following systems and the manual enforcement method, thus preventing the conventional approach of the supply chain from suffering the wrong impact [10]. Figure 1 shows the proposed framework for this study.

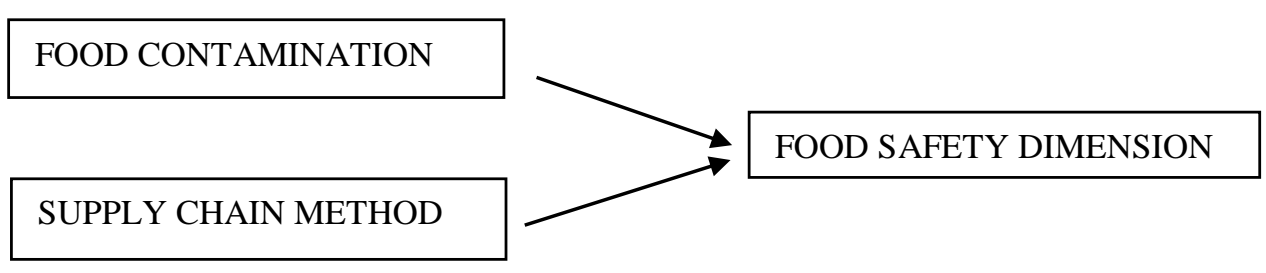

Figure 1: Framework to proceed

\section{Conclusion and Recommendation}

In conclusion, this study highlights the significance and impact of food contamination and supply chain management on food safety. Food safety is a concern for the food industry to comply with the regulation, increase revenue, and consumer trust in the food produced. A framework for further research in this study is proposed based on the identified issues regarding food contamination and the supply chain.

\section{Acknowledgements}

Acknowledgements. Special appreciation to Universiti Teknologi MARA, Cawangan Pulau Pinang for providing the budget for this research study.

\section{References}

[1] M. of H. Malaysia, "Kenyataan Akhbar Ketua Pengarah Kesihatan Malaysia; Kejadian Keracunan Makanan di Sekolah Seluruh Malaysia,” Minist. Heal. Malaysia, 2016.

[2] W. Salleh, M. N. Lani, W. Z. W. Abdullah, T. Z. T. Chilek, and Z. Hassan, "A review on incidences of foodborne diseases and interventions for a better national food safety system in Malaysia," Malaysian Applied Biology. 2017. 
[3] H. M. Lam, J. Remais, M. C. Fung, L. Xu, and S. S. M. Sun, "Food supply and food safety issues in China," The Lancet. 2013, DOI: 10.1016/S0140-6736(13)60776-X.

[4] J. Zhang, D. L. Mauzerall, T. Zhu, S. Liang, M. Ezzati, and J. V. Remais, "Environmental health in China: progress towards clean air and safe water," The Lancet. 2010, DOI: 10.1016/S0140-6736(10)60062-1.

[5] M. M. Aung and Y. S. Chang, "Traceability in a food supply chain: Safety and quality perspectives," Food Control, vol. 39, no. 1, pp. 172-184, 2014, DOI:

10.1016/j.foodcont.2013.11.007.

[6] D. Mao, Z. Hao, F. Wang, and H. Li, "Novel Automatic Food Trading System Using Consortium Blockchain,” Arab. J. Sci. Eng., 2019, DOI: 10.1007/s13369-018-3537-z.

[7] A. Regattieri, M. Gamberi, and R. Manzini, "Traceability of food products: General framework and experimental evidence," J. Food Eng., vol. 81, no. 2, pp. 347-356, 2007, DOI: 10.1016/j.jfoodeng.2006.10.032.

[8] F. Tian, "A supply chain traceability system for food safety based on HACCP, Blockchain \& Internet of things," 2017, DOI: 10.1109/ICSSSM.2017.7996119.

[9] C. N. Verdouw, J. Wolfert, A. J. M. Beulens, and A. Rialland, "Virtualization of food supply chains with the internet of things," J. Food Eng., vol. 176, pp. 128-136, 2016, DOI: 10.1016/j.jfoodeng.2015.11.009.

[10] D. Tse, B. Zhang, Y. Yang, C. Cheng, and H. Mu, "Blockchain application in food supply information security," 2018, DOI: 10.1109/IEEM.2017.8290114. 